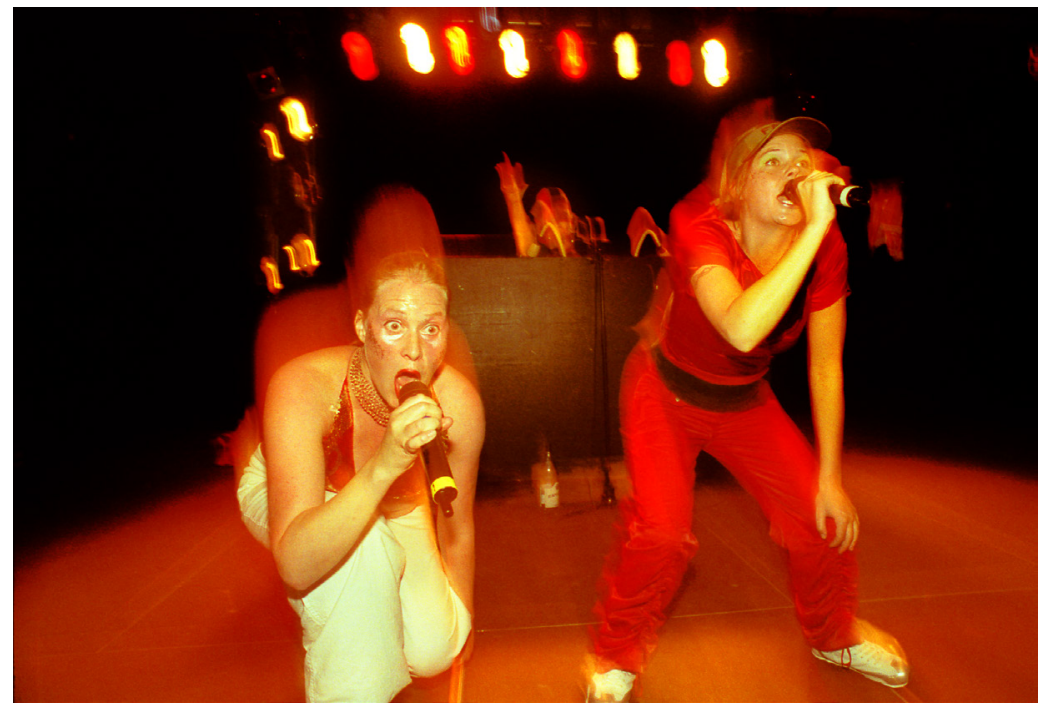

D Muttant (Maya Hald) and Y Puss (Åse Fougner) performing D Muttant's Mission in 2005. Photographer: José Figueroa. Copyright CC-BY-NC-ND. 


\section{Solidarity Lost and Found: Reflections on Contemporary Feminist Performance}

As the millennium began, performance and art have shown a resurgence of interest in politics, everyday life, and the documentary. A political agenda has been reinstated that intends to not only portray but also challenge the post-political Zeitgeist and the vision of politics as a consensual form of democracy. However, nothing "just suddenly" becomes political. Political performance had not entirely disappeared from Sweden at the end of the I970s. Theatre companies and projects with a political orientation could always be found, although political tendencies in Swedish theatre grew stronger in the late I990s and were increasingly noticeable by the turn of the new century.

The background of contemporary feminist performance in Sweden can be located in the shift from a social democratic state to a neoliberal one. In civil society, the distinction between the two can be assessed by the extent of personal freedom enjoyed by the populace, including sexual and reproductive rights, and whether interpersonal civic transactions are typified by commercialization

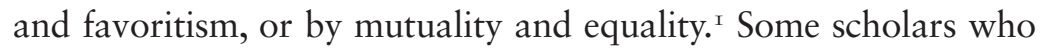
have tried to summarize the era of postmodernism have pointed to the September I Ith attacks of 200I as the symbolic reason for a major shift in political theory and practice. ${ }^{2}$ Aggressive neoliberal right-wing economic politics, the war against terrorism, climate change, increasing global inequality, poverty, and the lack of social justice are the principal reasons for the reappearance of class issues in critical theory, feminist politics, and performance. The third way of thinking beyond the political left and right is dismissed by Chantal Mouffe in On the Political (2005), where she urges passion

How to cite this book chapter:

Rosenberg, Tiina 2016. Solidarity Lost and Found: Reflections on Contemporary Feminist Performance. In: Rosenberg, Tiina Don't Be Quiet, Start a Riot! Essays on Feminism and Performance. Pp. I 84-205. Stockholm: Stockholm University Press. DOI: http://dx.doi.org/Io.I6993/baf.j. License: CC-BY 4.0 
in politics and stresses the importance of creating forms of antiessentialist collective identification around democratic objectives. ${ }^{3}$

\section{Hope in negative times}

Postmodern theory and performance have insisted on depression and negativity to such an extent that one hardly knows where to launch a counterargument. As theatre scholar José Estaban Muñoz points out, it is difficult to advocate hope or critical utopianism when cultural analysis is dominated by the opposite. ${ }^{4}$ Queer theorist Lee Edelman's famous polemic, No Future: Queer Theory and the Death Drive (2004), is only one example of this obsession with negativity. In it he speaks of "the structuring optimism of politics of which the order of meaning commits us. Installing as it does the perpetual hope of reaching meaning through signification, is always, I would argue, a negation of this primal, constitutive and negative act." ' Political hope fails queers because it is heteronormative and resonates only on the level of reproductive futurity. Giving up futurity and the death drive is what Edelman recommends. He advocates identification with the negative: the enemy of the future, the enemy of the state, and the enemy of the child as a symbol of the future.

A critical intellectual, however, need not be a negative one. Negativity strongly influences the contemporary intellectual opinion industry, which profits from rapid consumption of all kinds of cultural products. An objection to this overtly negative trend should not be based on the populist ideology of happiness and compulsory optimism that is created by the feel-bad-becomesfeel-good formula of popular psychology and consumerist capitalism. While negativity is an important artistic technique, it is not necessarily a criterion for art. When the Austrian Nobel Prizewinning playwright and novelist Elfriede Jelinek announced that her creativity comes out of negativity and that she could not write anything positive, it sounded like a manifesto. "There is nothing programmatic in writing about negative things. Unfortunately, I only see negative things; and I can only describe what I see, what I have experienced, and what I know about the world." 6

Another example of an extremely negative aesthetic is the work of British dramatist Sarah Kane, whose dark, brutal visions have already achieved mythical status. In five dramas, she radically 
criticizes a culture that anaesthetizes rather than questions our contemporary state of mind. ${ }^{7}$ Blasted (I995) opens with Ian and Cate in a hotel room in Leeds. Suddenly the drama explodes: Ian rapes Cate. A war begins and the hotel is bombed. The dialogue consists of lyrical, rhythmic, short sentences. When the play is over, Ian concludes the performance by saying, "Thank you." Kane also invokes an ancient past in her Phaedra's Love (1996), in which Hippolytus refuses to participate in the corruption around him, but is finally brought down by self-hatred. Kane continues in the tradition of Samuel Beckett, but with an important difference: While Beckett sought to work out a drama for post-war Europe after Auschwitz and the Holocaust, Kane only sees darkness, and her vision for postmodern times carries with it very little hope.

Kane's provocations encourage her audience to react. For her, theatre is not an escape from the world but a confrontation with it. Everything can be (re)presented on stage. To say that something cannot be performed on stage is, in Kane's theatre, like saying one dare not mention it. That denial is an ethical statement. Our human relations are the networks that keep us alive in a world where we find ourselves tormented, weak, and helpless. Kane's play Cleansed (1998) is perhaps the best metaphor for this. The world is all about darkness, and in that darkness we must learn how to love in order to survive.

As in Edelman's No Future, religious overtones may also be found in Kane's writing. After the cataclysm a little light, such as that glimpsed at the end of Kane's play Crave (I998), may be seen. God is dead and the remaining human beings are trying to find some meaning in life by relating to other humans. It is not the first time theatre has been used to represent existential and religious issues. Pain and isolation can be bridged by communication, if communication is even possible. "It is my belief," Muñoz writes, "that minoritarian subjects are cast as hopeless in a world without utopia. That is not to say that hope is the only modality of emotional recognition that structures belonging; sometimes shame, disgust, hate and other 'negative' emotions bind people together."

Our communication culture, and especially the genre of outspokenness, has changed in recent years. The culture of rudeness and cruelty in Facebook's hate pages is a socially accepted form of bullying. Kane, who died by her own hand in I999 at the age of 
28, must have had some faith in communication or she would not have bothered writing. Her experimental language and the image of suffering in her writing comes close to Jill Dolan's "moments of liminal clarity and commission, fleeting, briefly transcendent bits of profound human feeling and connection, [that] spring from the alchemy between performers and spectators and their mutual confrontation with a historical present that lets them imagine a different, putatively better future." 9

\section{Paradise lost: The social democratic utopia}

The climate for taking a political stand was not entirely absent from the postmodern I980s and early I990s. Then, after the turn of the century, Sweden experienced an explosion of feminist performance as direct actions, theatre, shows, and events with a distinctive approach emerged in force. Many feminist cultural festivals were held, and individual feminist performance, dance, and theatre events sometimes attracted even broader audiences than festivals. This popularization of feminist performing arts is related to the lively climate of feminist activism in Sweden. Just as activism in the I990s was reshaped by the political climate of the decade, activist art also reflects the art and theatre world of the 200os. However, as Mouffe cautions, with the increasing acceptance of their feminist activist work, artists must resist being neutralized by capitalism. One of the most urgent and contentious issues the feminist left has had to deal with is the downscaling of the Swedish welfare state. For many, the Swedish project of establishing a social democratic, egalitarian, liberal, and open society has changed beyond recognition.

The assassination of the social democratic Prime Minister Olof Palme in I986 meant a loss of Swedish innocence in many ways. It also affected the public's confidence in the future. Palme was the subject of two 200I plays, Olof Palmes leende (Olof Palme's Smile) by Malin Lagerlöf at the Länsteatern in Örebro, and Palme dör innan pausen (Palme Dies Before the Intermission) by Stefan Lindberg at Teater Bhopa in Gothenburg. The Swedish band Latin Kings put music to Olof Palme's speech on social exclusion and discrimination, and the feminist artist Malin Arnell's series Jag ser vad du säger (I See What You're Saying), a slide presentation 
of slogans, included a photo of "I shot Olof Palme" scribbled in Swedish on a wall in Barcelona. At the Academy of Art in Malmö, Olof Palme gazed with a Che Guevara stare from a blood red t-shirt created by the artist Olaf Unnar. One of the latest outraged reactions against the Swedish right-wing government was the 2010 election video Grät allians av vart hat (Crying out to a government we hate) by the Queer Institute in Gothenburg. The term alliance refers to "Alliansen", as the right-wing coalition calls itself. The video is a rallying cry for action against the government and its policies. In works such as these, young dramatists and artists have called into question the downsizing of the social democratic project and the fading dream of a model welfare society that greeted their generation as it reached adulthood.

Interest in Olof Palme has reemerged in a number of biographies, and in director Carolina Frände's 2009 collage production of Palme at the Uppsala City Theatre. It appears to represent not only nostalgia for Palme, but the public mourning of the lost vision of a social democratic nation as well. For younger Swedes the story of Olof Palme begins with his assassination on Sveavägen in central Stockholm in I986. This brutal act, the confused and confusing police investigation that followed, the various conspiracy theories that flourished in the media, and the eventual capture of a murder suspect who was later released, constitute a national trauma that has never entirely healed.

\section{Thanking Olof Palme}

Lo Kauppi, a feminist performer, is grateful for her upbringing in social democratic Sweden. Her performance, Bergsprängardottern som exploderade (The Rockblaster's Daughter Who Exploded), was one of the most successful shows of the 2004-2005 season. In it Kauppi delivered a naked, powerful, and candid account of her life and class origins, conveying to her audience both social reportage and the energy to keep going: "It felt like I had gone through drama school just to be able to tell this story," she has said. ${ }^{\text {I0 }}$ Many who were present wanted to hear it.

Kauppi's life story was not just a private anecdote, but also a fierce political criticism of cutbacks in social programs and the 
curtailment of health services. Her fury drove her presentation. Kauppi pointed out that no one at drama school understood what she meant by political theatre: "I felt so lost-what if I had chosen the wrong profession? And now it has all fallen into place. I was able to do political theatre after all." ${ }_{\text {II }}$ Her one-woman show sums up how much she has cost society and how much cheaper it would have been had she been given proper treatment when she began having medical problems around the age of fourteen. In her teens she tried to resolve her inner chaos by dieting. Her eating disorder increased in the midst of a working-class family of addicts who used to argue about who was the sickest. This was followed by years of drug abuse and other social problems. "I'm incredibly grateful that I grew up in Olof Palme's Sweden. It doesn't matter what the Conservatives say. I would never have survived in a more competitive society," she states, thanking Sweden's social democratic system for her life. ${ }^{12}$

With her performance in Bergsprängardottern som explodera$d e$, Kauppi felt she was able to obtain forgiveness and acceptance at last. Performance was her means of expressing her feelings. Fully aware that it would require her to put her body on stage - the body that she had been trying to alter since she was fourteen - she took the risk.

I have done so many stupid things in my life; robbed, fought, and injured myself in lots of different ways, and I always thought everything was my own fault, that I only had myself to blame. But now that I'm older, I realize that everything might be connected and that perhaps we do things simply because we have to when we are small, and that everything was really just a cry for help that was about making dad stop drinking. I'm not trying to avoid responsibility, just trying to explain. To explain why I did all those things. To show that there might be a reason why some people behave like idiots and one shouldn't get mad at those who fail. To show what it's like to be a teenager and realize that you're not actually a human being, but a woman condemned to be an object to make old men horny that everybody has the right to criticize and put down, and how hard it is to defend yourself against the constant advertisements with anorexic models, when everything is chaos at home and there's nobody who can tell you you're fine just 
the way you are. How that sort of thing affects your life and gets too heavy for some of us. ${ }^{13}$

Kauppi's leftist-feminist performance was televised in 2010, and she has continued to work in this political direction since then. Her more recent performances discuss themes such as sexism, power, and poverty in a society that has lost its focus on solidarity. Kauppi's anger can be understood in the sense, as Mouffe points out, that Europe is now faced by the unchallenged hegemony of neo-liberalism that claims there is no existing order. ${ }^{I 4}$ This view has been accepted by social democratic parties which under the pretense of modernizing, have been steadily moving to the right, while at the same time redefining themselves as center-left. According to Mouffe, rather than profiting from the crisis of its old communist antagonist, social democracy has been dragged until it collapsed. ${ }^{\text {I5 }}$

In this way, a great opportunity has been lost for (social) democratic politics. The events of 1989 in Europe should have been the occasion for a redefinition of the Left, now relieved of the pressure previously put upon it by the Soviet system. Mouffe suggests that there was a real chance for a deepening of the democratic project at the time, since traditional political frontiers had been shattered and could have been redrawn in a more progressive way. Unfortunately, this chance has been missed in Sweden and everywhere in Europe. "Instead we hear triumphalist claims about the disappearance of antagonism and the advent of a politics without frontiers, without a 'they': a win-win politics in which solutions could be found favoring everybody in the society." ${ }^{16}$

\section{Activist aesthetics and the street}

Feminist, queer, anti-racist, and class-based performances take us onto the streets. Since the breakthrough of New Circus in the I980s and I990s, the performing arts has become a realm where the borders between dance, acrobatics, and acting have been dissolved. Theatre and performance have been enticed and seduced by reality; Shakespeare alone is not enough. Social movements seeking gender, sexual, class, racial, and ethnic liberation have taken 
the form of demonstrations, protests, guerrilla theatre, music, poetry, visual culture, and media events unfolding on the "street", that is, in public space. ${ }^{17}$ Art historian Nina Felshin points out that the hybrid cultural practice called art activism is shaped as much by the "real world" as by the art world. Writing in I995, she stated that

activist art represents a confluence of the aesthetic, sociopolitical, and technological impulses of the past twenty-five years or more that have attempted to challenge, explore, or blur the boundaries and hierarchies traditionally defining the culture as represented by those in power. This cultural form is the culmination of a democratic urge to give voice and visibility to the disenfranchised and connect art to a wider audience. It springs from the union of political activism with democratizing aesthetic tendencies originating in Conceptual art of the late I960s and early I970s. ${ }^{18}$

Activist art requires community or public participation in order to effect social change and promote social justice. This can be accomplished by working in a variety of organizations, feminist, radical, or solidarity groups, labor unions, cultural task forces of small leftist parties, environmental, pacifist, LGBTQ, and anti-racist organizations - all groups offering ways to connect with those who share a common interest. ${ }^{19}$ Activist art, in the forms it takes and in the methods it uses, is process rather than an object or product-oriented endeavor. It takes place at public sites outside the context of the art world. In practice, it often appears as temporal interventions, such as performance or performance-based activities, media events, exhibitions, and pop-up installations.

Feminists in Sweden and abroad have used spectacular means to dramatize the many ways in which women are objectified by the prevailing cultural and social representation systems. For example, feminist action groups have organized counter-performances in connection with the Miss World and other beauty pageants by outfitting their own bodies with flashing lights attached to their breasts and crotches, or by decorating shop dummies with signs denigrating women. The "No More Miss America" demonstration in August 1968 launched the popular image of feminists as bra burners. Such an action was once again used by the Swedish 
feminist activist group Unfucked Pussy (Joanna Rytel and FiaStina Sandlund) in their Gubbslem (Slimy Old Men) action against the Miss Sweden pageant in 200I. The early street demonstrations and direct actions of the I960s and I970s triggered the body-centered critique of gender and sexual representations that dominated feminist theatre, theory, and practice in the I980s. ${ }^{20}$

When Swedish feminist artists adopted performance art as a legitimate form of stage presentation, it gave them greater freedom. Focus shifted from text and craftsmanship to thoughts and ideas. In performance art one may use whatever form of expression that most effectively conveys the topic at issue. The presentation centers on direct action, mixing such styles and genres as spoken word poetry, music, dance, circus, and elements of popular culture with various impromptu pranks and tricks thrown in. However, it also utilizes text-based traditions of theatre when required. The political arena is a space of power, conflict, and antagonism. Valid political questions always require one to choose between conflicting alternatives.

Next to antagonism, the concept of hegemony is a key notion for addressing the question of the "political." Mouffe links the political to the acts of hegemonic institutions. In this sense one has to differentiate the social from the political. ${ }^{21}$ Every order is political and based on some form of exclusion. There are usually other possibilities that have been repressed but can be reactivated. The articulatory practices through which a certain order is established and the meaning of social institutions is fixed are hegemonic. Every hegemonic order is susceptible to being challenged by counter-hegemonic practices, i.e., those that attempt to disarticulate the existing order in order to install another form of hegemony. ${ }^{22}$

\section{Actions in public space}

The heteronormative boundaries for women's bodies, and narrow definitions of femininity, are the central themes for the group of artists who call themselves the High Heel Sisters who physically explore concrete social settings. In their critiques of power, they seek to renegotiate the rules that determine social games. The group's methods - cooperation based on sisterhood - encourage 
women to support each other and finally lay to rest the myth of the genius male artist. On the assumption that gender is performative, the High Heel Sisters present exaggerated behaviors in diverse situations to emphasize how everything is a matter of social codes, and in this way they seek to undermine those codes.

The High Heel Sisters met at an art exhibition: "We were standing next to each other at an opening and discovered we had the same physical traits: we are taller than I.78, older than 30 , we take more than a $4 \mathrm{I}$ size shoe, and we had beautiful, hairy legs. We felt that this was power." ${ }^{23}$ The artistic method of the High Heel Sisters consists in the group setting themselves a particular assignment or choosing a situation to be explored. For their first performance they assigned themselves tasks to solve in the course of one day, namely, how long could they hang from a tree together and stand still together under specific circumstances that would allow them to study their own physical limitations and the confining normalization mechanisms of society: What determines whether something is art or not?

To Walk Together Across a Square (2003) was a work in which the High Heel Sisters invited women to assemble and walk with assurance across Sergel's Square in Stockholm for a given period of time. The invitation read:

The High Heel Sisters invite you and all other women to walk back and forth with determined steps across Sergel's Square for an hour. Devote one hour to walking together across a plaza. You are welcome to take part on Wednesday, 27 August, from I2 to I pm. Instructions: walk with determined steps, slowly and proudly, towards a fixed point on the other side of the plaza. When you reach it, turn around and fix your gaze on a new point, etc. Do not speak while doing this. Feel that we own the place. ${ }^{24}$

The purpose of the action was to create an ownership relationship vis-à-vis Sweden's most public space, to gain a physical experience of redefining gender, and to give other women an opportunity to share this experience. Another work, Never Too Much (2004), reverses the striptease. The High Heel Sisters started the performance nude, reading aloud from books by Gertrude Stein, Judith Butler, and Julia Kristeva, then eventually got up on stage and put 
their clothing on. The group's actions and activities are used as a way of creating and then inhabiting social situations to reveal power relationships at different levels.

Malin Arnell of the High Heel Sisters and Fia-Stina Sandlund also organized a public reading of Zoe Leonard's I 992 manifesto I Want a President. Standing on the steps of Sergel's Square, they gathered women together to recite and sing a slightly modified version of the following lines on the day before national elections were held in Sweden in September 20I0:

I want a dyke for president. I want a person with AIDS for president and I want a fag for president and I want someone with no health insurance and I want someone who grew up in a place where the earth is so saturated with toxic waste that they didn't have a choice about getting leukemia. I want a president that had an abortion at sixteen and I want a candidate who isn't the lesser of two evils and I want a president who lost their last lover to AIDS, who still sees that in their eyes every time they lay down to rest, who held their lover in their arms and knew they were dying. I want a president who has stood on line in a clinic, at the $\mathrm{DMV}$, at the welfare office, and has been unemployed and laid off and sexually harassed and gay-bashed and deported. I want someone who has spent the night in the tombs and had a cross burnt on their lawn and survived rape. I want someone who has been in love and hurt, who respects sex, who has made mistakes and learned from them. I want a black woman for president. I want someone with bad teeth and an attitude, someone who has eaten that nasty hospital food, someone who cross-dresses and has done drugs and been in therapy. I want someone who has committed civil disobedience. And I want to know why this isn't possible. I want to know why we started learning somewhere down the line that the president is always a clown: always a john and never a hooker. Always a boss and never a worker, always a liar, always a thief and never caught. ${ }^{25}$

Jane Mansbridge calls this "practice-oriented activist knowledge" or "street theory," in contrast to theories produced within the academy. Street theory is created in and by communities. Sometimes these ideas are picked up by academic scholarship, rearticulated, redefined, and end up meaning something other than they did in 
their street period. It is problematic that historians who chronicle political movements rarely address parallel currents in academic writing, and academic theorists are not consistent about acknowledging the influence of direct-action politics on their scholarship. ${ }^{26}$

\section{Humor}

The idea of combating repression with pranks and wry humor has ancient roots. In contemporary feminist art activism, the Guerrilla Girls, who by now are veterans of feminist cultural resistance, describe themselves as fighting discrimination with facts, humor, and fake fur. Another activist group, Absurd Response To An Absurd War, proclaims that the way to maintain today's anti-war message is through humor, theatre, music, flamboyance, irony, and fun. The Plutonium Players, a performance group, were aware of this when they launched their project "Ladies Against Women" (LAW) in the US in the I980s. Dressed as drag queens who, in turn, were dressed as Nancy Reagan and her friends, LAW used the familiar activist tactics of satire, coup, and parodying the enemy. Their favorite settings were Republican gatherings such as Reagan's prayer breakfasts, where they blended in with the crowd and inserted slogans listing ingredients such as "white sugar, white flour, white power" in the pies.

Political agitation often uses humor because it is so disarming. Although frustration may help drive the feminist activist, humor is communicative and makes the audience feel included rather than accused. Common to most of these acts, and setting them apart from I970s feminist theatre, is their unique form of political agitation that includes a considerable amount of monologue, performance, and elements of popular culture. The performance artist Maya Hald's alter ego, D Muttant, is an example as she raps her message:

I want women who see my show to feel encouraged by the fact that D Muttant does what she does. But they don't have to agree with everything. But I want to convey an allowing message that "I can do anything at all." There are more and more of us. There are masses of feminist performing artists who are beginning to be established, but also a multitude of up-and-coming ones who will 
carry on the work. This is not something that will disappear in the next few years. ${ }^{27}$

In the mid-20oos D Muttant has sometimes appeared with Y Puss (Åse Fougner) as a double feminist hip-hop act, although the duo preferred not to be pigeonholed. Their music was based on simple beats produced by a toy drum machine. The sound was monotonous, with rough cuts and sudden changes. Their concept was that feminism comes first and that hip-hop is a secondary tool for shouting out their message. In this case that message was unmistakable: women continue to be marginalized. Y Puss/D Muttant wanted to change the balance of power. D Muttant was dressed in net stockings under a red latex dress with a triangular hole over her crotch. On her head, she wore a green hat emblazoned with the Swedish word subba (bitch). Y Puss wore pink trousers with pockets and studs, a pink glittery vest, and a woolly hat.

Following in the footsteps of older feminist sisters, the younger feminist generation has given the cunt a face, as the name of the activist group Unfucked Pussy and the 2005 show Lilla Fittan på prärien (Little Cunt on the Prairie) by the comedy group PomoDori both demonstrate. Now as before, feminists present the female genitalia to show that this is still a sensitive subject. Little Cunt on the Prairie echoes the popular Little House on the Prairie, where everyone was always so good and kind; but here the similarities end. The group culled their material from actual situations they had experienced in daily life. A great deal concerned the insistence on being a happy person and the dominant social norms for women. The group tried to articulate the way many people go around feeling that they are some kind of fake. PomoDori wanted to get at the "loser" we all have inside us. Although their humor was sophisticated, PomoDori also took the liberty to be rude, physical, ugly, and coarse in the same way men are. They also challenged the fact that men write much of what is performed by women in mainstream theatre. This causes women to remain the lackeys of men, rather than have the freedom to rebel. PomoDori resolved this in their own case by working as an all-women ensemble. 


\section{The activist artist as an organic intellectual}

Mouffe asks whether artistic practices can still play a critical role in a society where the difference between art and advertising has become blurred, and where artists and cultural workers have been co-opted and made part of capitalist production. She notes that while artistic endeavors can figure in the struggle against capitalist domination, this would require understanding the dynamics of democratic politics. ${ }^{28}$ Cultural democracy is as much a right as economic and political democracy. One way to achieve this is to practice solidarity. Sara Ahmed classifies feminist emotions as anger, wonder, and hope, resulting in solidarity. Anger awakens the feminist and keeps her going. Wonder lets her see the world as if for the first time. Hope reminds her that concern for the future must be bound up with the legacy of the feminist past. "For feminists, a political and strategic question remains: When should we let go? And what should we let go of? Such a question has no immediate resolution: we must decide, always, what to do, as a decision that must be made again, and again, in each present we find ourselves in." ${ }^{29}$ Hence, one should not make feminism the object of our hope, even if it does give us hope. Ahmed sees Chandra Talpade Mohanty's vision of transnational solidarity as one way to approach feminist strategies for the future.

For Mohanty, political scientist Jodi Dean's notion of reflexive solidarity as an interaction involving three people is helpful. The thematizing of the third voice is to reconstruct solidarity as an inclusive ideal, rather than an "us versus them" dichotomy..$^{\circ}$ Mohanty praises Dean's idea of a communicative in-process understanding of the "we," since solidarity is always an achievement - the result of the active struggle to construct the universal on the basis of particulars and differences. ${ }^{3 \text { " }}$ "It is the praxis-oriented, active political struggle embodied in this notion of solidarity that is important to my thinking - and the reason I prefer to focus attention on solidarity rather than on the concept of 'sisterhood,", Mohanty writes..$^{32}$ She finds feminist solidarity the most principled way to cross borders, decolonize knowledge, and practice anti-capitalist criticism. While not implying that women's lives and struggles are the same everywhere, she nevertheless finds them 
comparable. Therefore, Mohanty argues for political solidarity, which she understands as a community or collectivity among women workers that reaches across class, race, and national boundaries, and is based on shared material interests and common ways of reading the world. For this reason she sees solidarity as the basis for mutually accountable and equitable relationships among different communities of women. ${ }^{33}$

If one takes feminist activist artists together with Mohanty's notion of practiced and decolonized solidarity and combines them with Antonio Gramsci's idea of the intellectual, we arrive at one possible way to engage with social movements, the academy, and the arts. Gramsci saw the intellectual as essential to countering hegemony, and he identified two types of intellectuals: traditional and organic. ${ }^{34}$ This distinction may be applied to artists as well.

The first type would consist of artists who regard themselves as autonomous. The general population views them as independent of the dominant social group. Traditional intellectuals give themselves an aura of historical continuity, despite the social upheavals they might have experienced. They are essentially conservatives, allied to and assisting the ruling group in society. The second type, the organic intellectual, includes activist artists. This group grows as a matter of course alongside the dominant social group, for which it acts as its thinking and organizing element. Gramsci saw that organic intellectuals were produced by the educational system to perform a function for the dominant social group, for through them the ruling class maintains its hegemony. ${ }^{35}$ In his Prison Notebooks from 1929 to I935 Gramsci wrote that not only should a significant number of traditional intellectuals join the revolutionary cause, but that the Left should produce its own organic intellectuals. He considered it one of his roles to assist in the creation of such individuals from the working class, while winning over as many traditional intellectuals as possible. The intellectual realm, as he understood it, was not confined to an elite but grounded in everyday life. "The mode of being of the new intellectual can no longer consist in eloquence . . . but in active participation in practical life, as constructor, organizer, permanent persuader, and not just a simple orator." ${ }_{36}$ 


\section{Agonistic struggle}

The ideal for a feminist performer is to combine Mohanty's notion of solidarity with Gramsci's idea of the organic intellectual. The organic feminist artist is the activist guerrilla performer connecting the art world with social movements and politics in a broad sense. Political mobilization, Mouffe writes, requires politicization, but politicization cannot exist without the production of a conflictual representation of the world. ${ }^{37}$ People in general, including artists, identify with different political camps. Organic feminist artists can contribute to the political struggle via passionate performances as a way to mobilize audiences politically within the spectrum of the democratic process.

The primary object for feminist organic artists is to make social conflicts visible. Mouffe points out that in order for a conflict to be accepted as legitimate, it needs to have a form that does not destroy its political association. Therefore, a common bond must exist between the parties in conflict, so that they will not simply treat their opponents as enemies to be eradicated. ${ }^{38}$

Mouffe makes a distinction between agonistic and antagonistic. An agonistic struggle is a conflict between opposing hegemonic projects that can never be reconciled rationally. According to Mouffe, the antagonistic, which is always present, is a real confrontation, but is played out under conditions regulated by democratic procedures accepted by the adversaries. ${ }^{39}$ She believes that instead of trying to design institutions that would reconcile all conflicting interests through supposedly impartial procedures, an effective exercise of democracy for theorists and politicians would be to envision a vibrant agonistic public sphere, where hegemonic political projects could freely confront one another. ${ }^{4}$

\section{Conclusion}

Feminist performers, particularly in Sweden, have challenged the supposedly post-political Zeitgeist of our time. The shortcomings of the post-political approach should force us to think beyond Left and Right. However, the critical utopianism of the Left has been difficult to promote at the present moment, when cultural analysis is so dominated by anti-utopianism. Nevertheless, feminist 
performers do contribute to sustaining that utopianism. It has been recommended that the feminist performer identify herself as a feminist organic artist invested in a feminist understanding of solidarity. This approach to performance and politics should be from an agonistic, rather than antagonistic, perspective by providing legitimate forms of expression for political conflicts. In this way social dissent would not undermine democracy, but would be a challenge that invigorates democratic politics. ${ }^{4 \mathrm{I}}$

\section{Notes}

I. Walby, Globalization, 279.

2. Anderson, Origins of Postmodernity; Eagleton, After Theory; Cusset, French Theory; Davis, After Poststructuralism; Hill \& Birchall, New Cultural Studies; Jameson, Postmodernism.

3. Mouffe, On the Political.

4. Muñoz, Cruising Utopia, 9.

5. Edelman, No Future, 3.

6. Quoted in Schueler, "Allt ljus på Jelinek.”

7. Kane, Complete Plays.

8. Muñoz, Cruising Utopia, 97.

9. Dolan, Utopia in Performance, I68.

Io. Quoted in Skawonius, "På korståg."

I I. Ibid.

I2. Ibid.

I3. Quoted in Poppius, "Förebilden."

I4. Mouffe, On the Political, 3 I-32.

I 5 . Ibid.

I6. Ibid.

I 7. Felshin, “Introduction,” I I.

I 8. Ibid., Iо.

I9. Lippard, “Trojan Horses.” 
20. Aston, Feminist Theater Practice, 5; Rosenberg, "Stockholm Interventions."

2I. Mouffe, On the Political, I7.

22. Ibid., I 8.

23. E-mail from High Heels Sisters, 26 Aug 2003.

24. Ibid.

25. Leonard, “I Want a President.” www.a.s.b.com. Accessed 29 Sept 2010.

26. Mansbridge, "What Is a Feminist Movement?” 29.

27. Kalmteg, "Feministiska föreställningar.”

28. Mouffe, "Artistic Activism”, I.

29. Ahmed, The Cultural Politics of Emotion, I 88.

30. Dean, Solidarity of Strangers, 3.

3 I. Mohanty, Feminism Without Borders, 7.

32. Ibid.

33. Ibid., I93.

34. Gramsci, Prison Notebooks.

35. Ibid., Io.

36. Ibid., Iо.

37. Mouffe, On the Political, 24-25.

38. Ibid., 20.

39. Ibid., 2 I.

40. Ibid., 3 .

4I. Ibid., 4 .

\section{Works Cited}

Ahmed, Sara. The Cultural Politics of Emotion. New York: Routledge, 2004. 
Anderson, Perry. The Origins of Postmodernity. London: Verso, I 998. Aston, Elaine. Feminist Theater Practice: A Handbook. London: Routledge, I999.

Cusset, Francois. French Theory: How Foucault, Derrida, Deleuze and Co. Transformed the Intellectual Life of the United States. Minneapolis: University of Minnesota Press, 2008.

Davis, Colin. After Poststructuralism: Reading, Stories, and Theory. London: Routledge, 2004.

Dean, Jodi. Solidarity of Strangers: Feminism after Identity Politics. Berkeley: University of California Press, 1996.

Dolan, Jill. Utopia in Performance: Finding Hope at the Theater. Ann Arbor: University of Michigan Press, 2005.

Eagleton, Terry. After Theory. London: Allen Lane, 2003.

Edelman, Lee. No Future: Queer Theory and the Death Drive. Durham, NC: Duke University Press, 2005.

Felshin, Nina, ed. "Introduction." In But Is It Art? The Spirit of Activism. Seattle: Bay Press, I994.

Gramsci, Antonio. Selections from the Prison Notebooks. London: Lawrence \& Wishart, I97I.

Hallin, Eva. "Med motstånd mot förändring: Samtal med Sapphos döttrar, High Heel Sisters, Johanna Gustafsson och Fia-Stina Sandlund" ("Resistance and Change: A Conversation with Sappho's Daughters, High Heel Sisters, and Fia Stina Sandlund"). In Konstfeminism: Strategier och effekter i Sverige frän I970-talet till idag (Feminism in the Arts. Strategies and Effects in Sweden from the I970s until Present), edited by Anna Nyström, Louise Andersson, Magnus Jensner, Anna Livion Ingvarsson, and Barbro Werkmäster, I 5 8-I 59. Stockholm: Atlas, 2005.

High Heel Sisters. Personal communication (e-mail), 26 Aug 2003.

Hill, Gary, and Clare Birchall, eds. New Cultural Studies: Adventures in Theory. Athens, GA: University of Georgia Press, 2007.

Jameson, Fredric. Postmodernism, or the Cultural Logic of Late Capitalism. Durham, NC: Duke University Press, I99I. 
Kalmteg, Lina. "Feministiska föreställningar fyller salongerna" ("Success for Feminist Performances"). Dagens Nyheter, 24 Aug 2005 .

_. "Feminister på scen senaste året" ("Feminists on Stage in the Past Year") Dagens Nyheter, 24 Aug 2005.

Kane, Sarah. Complete Plays: Blasted, Phaedra's Love, Cleansed, Crave, 4.48 Psychosis, Skin. London: Methuen Drama, 200I.

Leonard, Zoe. "I Want a President." Typewritten broadsheet widely circulated on the Internet. Original publication data unclear (I992?).

Lippard, Lucy. “Trojan Horses: Activist Art and Power.” In Art After Modernism: Rethinking Representation, edited by Brian Wallis, 34I-358. New York: New Museum of Contemporary Art, I984.

Mansbridge, Jane. "What Is the Feminist Movement?" In Feminist Organizations: Harvest of the New Women's Movement, edited by Myra Marx Ferree and Patricia Yancey Martin, 27-34. Philadelphia: Temple University Press, I995.

Mohanty, Chandra Talpade. Feminism Without Borders: Decolonizing Theory, Practicing Solidarity. Durham, NC: Duke University Press, 2003.

Mouffe, Chantal. On the Political. London: Routledge, 2005. . "Artistic Activism and Agonistic Spaces." Art and Research I (2007): I-5.

Muñoz, José Esteban. Cruising Utopia: The Then and There of Queer Utopia. New York: New York University Press, 2009.

Poppius, Kristoffer. "Förebilden: Lo Kauppi har en pjäs för att unga tjejer inte ska känna sig så fula och otillräckliga" ("The Role Model: Lo Kauppi Presents a Play for Young Girls who Should not Feel Ugly or Inadequate”). Dagens Nyheter, 20 Jan 2004.

Rosenberg, Tiina. "Stockholm Interventions: Feminist Activist Performance." In Staging International Feminisms, edited by Elaine Aston \& Sue-Ellen Case, 76-85. New York: Palgrave Macmillan, 2007.

Schueler, Kaj. "Allt ljus på Jelinek" ("Jelinek in the Spolight”). Svenska Dagbladet, 9 Dec 2004. 
Skawonius, Betty. "På korståg mot den sjuka vården: Lo Kauppis självbiografiska succépjäs går ut på turné” ("A Crusade Against Health Care: Lo Kauppi's Autobiographical Success Play on Tour”). Dagens Nyheter, I 8 Aug 2004.

Stjernö, Steinar. Solidarity in Europe: The History of an Idea. Cambridge, UK: Cambridge University Press, 2005.

Walby, Sylvia. Globalization and Inequalities: Complexity and Contested Modernities. London: Sage, 2009. 